\title{
$\mathrm{RDA}$ 구현 시나리오와 서지 제어의 장래에 대한 고찰"
}

\section{A Study for RDA Implementation Scenarios and Future Bibliographic Control}

\author{
조 재 인(Jane $\mathrm{Cho})^{* *}$
}

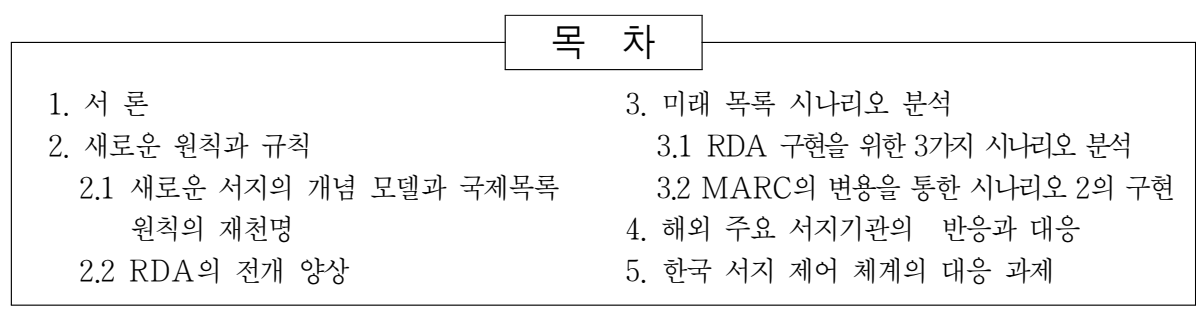

\section{초 록}

정보환경의 변화와 전통적 도서관 목록의 불일치에 대한 문제가 대두면서 영미를 중심으로 한 도서관계에서는 국제목록원칙을 재천명하였고, 올해 말 최종 발표를 앞두고 $\mathrm{RDA}$ 의 검토가 진행 중이다. JSC는 RDA에 $\mathrm{FRBR}$ 개념을 담아내면서도 수 십년간 고수된 $\mathrm{MARC}$ 을 존속시킬 수 있는 해법을 찾기 위해 다양한 수준의 구현 시나리오를 제시하고 있다. 본 논문에서는 첫 번째, 새로운 서지의 개념 모델인 FRBR과 최근 재천명된 국제목록원 칙규범을 살펴보고 이를 기반으로 전개된 $\mathrm{RDA}$ 의 구성과 특징을 분석하였다. 두 번째, $\mathrm{RDA}$ 구현을 위한 3 가지 시나리오를 통해 현행 MARC을 변용해 구현할 근접한 서지 제어 체계의 변화 내용과 FRBR 엔티티를 기반으로 시멘틱 웹 구조를 사용하게 될 미래의 목록 작성 작업을 분석하였다. 마지막으로 해외 주요 서지 기관의 대응 현황을 살펴보고 $\mathrm{RDA} / \mathrm{FRBR}$ 과 $\mathrm{KCR}$ 의 관계, $\mathrm{KORMARC}$ 의 변용 및 존속 여부, 전거 통제에 대한 대책이 시급한 우리나라 서지 제어 체계의 대응 방향을 제시하였다.

\section{ABSTRACT}

Disagreements between the technical environment and the conventional library catalog have caused a re-clarification of International Cataloguing Principles (ICP). Review is under way to finalize the publication of RDA (Resource Description and Access) in late 2009 by the Joint Steering Committee for Development of RDA. The impending RDA is based on FRBR (Functional Requirements for Bibliographic Records) which re-explains the bibliographic universe focused on entities, attributes and relationships between resources, but tries to maintain MARC as an encoding format for RDA. In this study, firstly FRBR, ICP and RDA were analyzed. Secondly, we propose 3 scenarios of RDA implementation: the future cataloging system based on the FRBR Entity, using a semantic web structure, and the scenario using the existing MARC format with some small changes. Finally, by examining response patterns of overseas bibliographic institutions, we present a set of urgent issues for future directions of bibliographic contro in Korea which includes, but not limited to, relationship between RDA/FRBR and KCR (Korean Cataloging Rules), continuation of KORMARC and authority control.

키워드: RDA, RDA 구현 시나리오, $\mathrm{FRBR}$, 서지제어, 국제목록원칙, $\mathrm{KORMARC}$, 전거통제 RDA, RDA Implemenation Scenarios, FRBR, International Cataloguing Principles, KORMARC, Authority Control

* 본 연구는 2009 시립인천전문대 내부연구과제 지원을 통해 수행됨.

** 시립인천전문대학 문헌정보학과 전임강사(chojane@icc.ac.kr) 논문접수일자: 2009년 8월 14일 최초심사일자: 2009년 8월 24일 게재확정일자: 2009년 9월 4일 한국문헌정보학회지, 43(3): 85-105, 2009. [DOI:10.4275/KSLIS.2009.43.3.085] 


\section{1. 서 론}

정보 탐색을 시작하는 응답자의 $84 \%$ 가 검색 엔진을 사용하며, 단지 $1 \%$ 만이 도서관 웹 사이 트를 이용하고 있다. 성능의 우위성에서 조차 양 측에는 큰 차이가 없다고 보고된 바 있어 (OCLC 2005), 전통적 도서관 목록의 존속 이 유는 더욱 무색해 지고 있다. 그동안 도서관의 $\mathrm{OPAC}$ 은 이용자들에게 원문 색인, 주제 분석, 자원의 식별, 전거 통제 등 지적인 지원을 요구 받아 왔다. 그러나 사서는 기술 목록에 집착해 왔고, 소급 입력 등의 정리 업무가 그 요구에 우선해 왔다(Markey 2007). 더불어 검색 엔진 에 비해 현저하게 떨어지는 경제성의 문제까지 제기되면서 아래와 같은 목록의 위기론이 대두 되게 되었다.
이러한 배경 속에 국제 도서관협회와 영미 목록계는 전통적 서지 제어 방식에 대한 전면 적 검토에 들어가게 되었고, 그 결과로 목록의 새로운 원칙과 규칙을 제정하게 되었다. 1998 년에 이미 FRBR(Functional Requirements for Bibliographic Records)이라는 목록의 새 로운 개념 모델이 제시되었으나, 이를 기반으 로 하는 목록 원칙은 10 여년이라는 기간을 거 쳐 올해 초 드디어 재천명되었다. 한편, 전통의 AACR (Anglo-American Cataloguing Rules) 을 대체할 목록 규칙은 당초 $\mathrm{AACR}$ 의 연장선에 서 그려지고 있다는 점으로 비판의 대상이 되었 으나, 최근 FRBR 기반으로 구조와 용어를 대폭 변경하여, 이제는 최종 출간을 앞두게 되었다. $\mathrm{FRBR}$ 은 개체와 속성, 그리고 그들 간의 관 계와 그것을 생산한 개인/가족/단체에 대한 관

〈표 1〉목록의 위기론

\begin{tabular}{|c|c|}
\hline 구 분 & 내 용 \\
\hline $\begin{array}{l}\mathrm{LC}(2000) \text { "밀레니엄 } \\
\text { 을 위한 서지제어 } 200 \text { 주 } \\
\text { 년 기념 회의" }\end{array}$ & $\begin{array}{l}\text { 도서관의 서지 제어 방식은 고비용일 뿐 아니라, 이용 시간의 지연을 유발. 검색 엔진에 의한 원문 } \\
\text { 색인 기술은 고비용의 사서직을 대신할 수 있음. 차세대 서지 검색 시스템은 도서, 연속간행물, 녹음 } \\
\text { 자료, 영상 자료, 전자 자료 등 모든 자료의 망라적 발견과 이용 지원 필요 }\end{array}$ \\
\hline Marcum(2008) & $\begin{array}{l}\text { 구글 시대 연간 } 4,400 \text { 만 달러(LC 목록)를 소요하는 현행 목록 작성 작업은 비용 효과가 거의 부재. } \\
\text { 기술 목록을 간소화하고 남는 여력을 전거, 주제 분석, 자원의 식별과 평가와 같은 지적인 작업에 } \\
\text { 집중해야 함 }\end{array}$ \\
\hline $\begin{array}{l}\text { University of } \\
\text { California Library } \\
\text { (2006) }\end{array}$ & $\begin{array}{l}\text { 이용자는 구글이나 아마존과 같이 넓은 정보 공간을 망라하는 검색과 2차 정보에서 1차 정보로의 } \\
\text { 끊김없는(Seamless) 이동을 기대함. 전통적 도서관은 자료의 유형에 따라 각기 다른 접근 도구를 } \\
\text { 제공해 왔으며, 목록은 그 중 도서관 소장 자료에 접근하기 위한 수단일 뿐임. 이용자가 전문 지식을 } \\
\text { 가지지 않고도 필요한 것을 발견할 수 있도록 지원하는 것이 도서관의 책무임. 도서관이 정보 시장에 } \\
\text { 계속 존속하기 위해서는 메타데이터를 작성하고 접근점을 증가하며, 이용자에게 효율적인 서비스로 } \\
\text { 개편할 필요가 있음 }\end{array}$ \\
\hline $\begin{array}{l}\text { Calhoun(2006) “변화 } \\
\text { 하는 목록의 본질 및 다 } \\
\text { 른 검색 도구와의 통합" }\end{array}$ & $\begin{array}{l}\text { 검색 엔진의 등장으로 도서관 목록은 이미 제품의 라이프 사이클에서 쇠퇴기에 접어듬. 도서관 목록은 } \\
\text { 앞으로 아카이브의 특수 자료 같은 유일본을 대상으로 해야 할지 모름. 품질보다는 신속성을 제고하기 } \\
\text { 위해 카피 목록, 자동 처리 등 비용 삭감을 고려한 프로세스의 정비가 필요 }\end{array}$ \\
\hline $\begin{array}{l}\text { Danskin (2006) } \\
\text { “내일은 모르는 : } \\
\text { 목록 작업의 종말" }\end{array}$ & $\begin{array}{l}\text { 새로운 정보원의 출현으로 전통적 목록은 존재 가치를 상실. 목록 작업은 비용대 효과가 매우 나쁜 } \\
\text { 작업임. } \mathrm{OPAC} \text { 은 아마존, 구글 등 다른 검색 서비스와 경쟁해야 함. 현재의 } \mathrm{OPAC} \text { 은 접근점을 늘리고 } \\
\text { 네비게이션 기능을 충분히 활용해야 하며, 다양한 웹 기술의 통합을 통해 세상의 지식으로 안내하는 } \\
\text { 강력한 관문이 되어야 함 }\end{array}$ \\
\hline
\end{tabular}


계를 강조하고 있다. 따라서 평면적 구조를 가지 는 현행 인코딩 방식으로는 구현에 한계가 따를 수 밖에 없다. JSC(Joint Steering Committee for Development of RDA 2007)는 RDA(Resource Description and Access)에 새로운 개 념 모델인 FRBR을 담아내면서도, 구현에 있어 서는 수 십년간 고수된 $\mathrm{MARC}$ 을 존속시킬 수 있는 해법을 찾기 위해 다양한 수준의 시나리오 를 제시하고 있다. 복수개의 독립된 개체와 개 체간의 관계로 이루어진 관계/객체 지향형 구조 를 이상적 시나리오로 제시하였으나, 대안적으 로 현행 서지 구조를 기반으로 MARC의 변용 을 통해 구현 가능한 시나리오도 제시하고 있다.

$\mathrm{RDA}$ 의 채택은 경우에 따라 소급 데이터의 변 화와 업무 프로세스의 재구축, ILS(Integrated Library System) 의 개선을 필요로 하기 때문 에, 개발 동향과 구현 시나리오에 관한 이슈는 많은 서지 기관들에 의해 주목되고 있다. 해외 서지 기관들은 상호 공조하여 의견을 모으고 채택에 따른 비용과 혜택을 평가할 뿐 아니라, 독자적인 대응 방안을 마련하기 위하여 분주하 게 움직이고 있다.

우리의 목록계도 새로운 서지 제어 동향에 대하여 대응 가능하면서도 독자적인 개선 방향 에 대한 모색이 절실하다. 그러나 아직은 RDA 의 구조나 내용, 관련 동향이 단편적으로 소개 되고 있는 수준이다. 새로운 원칙과 규칙의 제 정 동향을 살펴보고, 실제 구현을 위해 논의되 고 있는 다양한 수준의 시나리오 분석을 통해 목록의 미래를 예측해 볼 필요가 있다. 더불어 우리 서지 제어 체계가 글로벌 환경 변화에 능 동적으로 대응하기 위해 당장 필요한 과제들을 도출해 보는 것도 중요한 의미가 있을 것이라
고 본다. 따라서 본 연구는 다음의 세 가지를 목표로 설정한다. 첫 번째, 서지의 새로운 개념 모델인 FRBR과 최근 재천명된 국제목록원칙 규범을 분석하고 이를 기반으로 개발되고 있는 $\mathrm{RDA}$ 의 전개 양상을 분석한다. 두 번째, $\mathrm{RDA}$ 구현을 위해 제안된 3 가지 시나리오를 분석하 여, 현행 MARC을 변용해 구현하게 될 근접한 서지 제어 체계의 변화 내용과 FRBR 엔티티 를 기반으로 시멘틱 웹 구조를 사용하게 될 장 래의 목록 작성 작업을 분석해 본다. 세 번째, 해외 주요 서지 제어 기관의 반응과 대응 방향 을 살펴보고, 우리의 서지 제어 체계 정비를 위 한 방향성을 제시해 본다.

\section{2. 새로운 원칙과 규칙}

목록의 위기론에서 언급한 것처럼 전통적인 서지 제어 방식은 다양한 매체를 수용함에 있 어서 부적적하며, 이용자들의 변화된 정보 이 용 행태와도 일치하지 않는다. 국제도서관협회 와 영미 목록계는 1998년 목록 원칙과 규칙에 기초가 되는 새로운 개념 모형인 FRBR을 발간 하였고, 그 이후 국제목록원칙규범을 재천명하 여 현대적 목록 규칙의 기반을 마련하였다 (IFLA 2009). 본 장에서는 이들 간의 관계와 주요 특징 그리고 전개 양상을 살펴보도록 한다.

\section{1 새로운 서지의 개념 모델과 국제목록원칙 의 재천명}

\subsection{1 새로운 서지의 개념 모형}

목록계는 1998년 서지적 세계를 개체와 관 
계에 의해 재해석하는 새로운 개념 모델로 FRBR을 발표하였다. 그 이후 계속적으로 모 형을 보완하고 확장시키기 위한 이론적 노력과 더불어 이를 현실의 서지 세계에 적용하기 위 한 시도를 병행하고 있다. FRBR 개념 모형과 적용에 관한 내용은 국내에서도 관련 연구에 의해 수차례 소개된 바 있으므로 생략하도록 하며, 여기에서는 모형 개발 이후 이루어졌던 다양한 주제의 논의들을 정리해 보도록 한다. 더불어 기존 체계를 기반으로 FRBR을 구현함 에 있어 나타날 수 밖에 없었던 제약과 한계에 대하여 살펴보고, 새로운 내용적 표준을 지향 하는 RDA가 실제 구현 방식을 선택하는 과정 에서 고민해야할 부분에 대해 함께 논해 본다.

FRBR 개념 모형은 1998 년에 개발된 이후, IFLA FRBR Reviw 워킹 그룹에 의해 유지 보완되고 있다. 표현형 워킹 그룹, 집합체 워킹 그룹 그리고 객체 지향 모델화를 검토하고 있는 FRBR/CRM Dialogue가 운영되고 있다. 워킹 그룹에서는 아래〈표 2〉와 같이 이용자 태스크 의 추가, 표현형 개념의 재정의, 집합적 실체에 관한 문제 등이 다루어지고 있다. 한편, FRBR 의 제 2 그룹은 당초 전거 레코드의 기능 요건으
로 개발되었으나, 2007년 레코드라는 용어를 데 이터로 변경하여 전거 데이터의 구조화된 참조 프레임인 FRAD(Functional Requirements for Authority Data)를 제시하는 방향으로 진 행되고 있다. 이는 개체간의 관계와 저작간의 관계 유형에 관한 정의를 강조하고 있으며 도서 관이 아닌 다른 영역에서도 참조할 수 있도록 확장성을 갖추고 있다. 또한 $\mathrm{FRBR}$ 을 객체지향 형으로 재분석하고자 하는 시도로 FRBRoo (FRBR-object oriented) 가 제안되기도 하였 다. 이는 박물관계와 상호 운용성을 확보하고 객체지향이라는 새로운 모델화에 의해 서지데 이타가 재검토되는 계기가 되었다. FRBRoo는 CRM(CIDOC Conceptual Reference Model) 구조를 근간으로 FRBR의 사상을 표현하고 있 는데, 서지적 실체를 정태적으로 파악하는 방법 과 의사 결정 등의 과정을 동적을 표현하기 위 한 방법 등이 보완되었다. 서지적 서계를 클래 스의 계층화와 프로퍼트의 계승이라는 관점에 서 해석한 $\mathrm{FRBRoo}$ 는 서지적 세계의 동적 과정 에 대한 표현과 저작과 파생 저작간의 관계, 속 성의 계승에 대한 표현이 가능하다고 평가 받고 있다(渡邊隆弘 2008).

〈표 2〉 IFLA FRBR Reviw 워킹 그룹의 주요 논의 내용(谷口祥一. 2007)

\begin{tabular}{l|l}
\hline \multicolumn{1}{c|}{ 주요 논의 주제 } & \multicolumn{1}{c}{ 내 용 } \\
\hline 이용자태스크의 추가 & navigate, contextualise, relate 추가 \\
\hline 표현형의 재정의 & $\begin{array}{l}\text { “어떠한 지적 예술적 내용의 변경도 표현형의 변경이 된다”에서 “스펠링, 구두점 } \\
\text { 등의 수정은 동일 표현형의 범위이다”라고 재정의. 스펠링, 구두점등의 수정은 } \\
\text { 동일 표현형의 범위로 정리 }\end{array}$ \\
\hline 집합적 실체의 검토 & $\begin{array}{l}\text { 구현형에서만 집합적 실현체를 마련하자는 논의와 더불어, 저작/표현형에서도 집합 } \\
\text { 적 실현체를 가지게 하는 논의로 이원화 }\end{array}$ \\
\hline 새로운 속성과 관계의 추가 & $\begin{array}{l}\text { 저작의 속성에 언어를 추가 } \\
\text { 음악번호, 조를 표현형 속성에 추가 }\end{array}$ \\
\hline 새로운 실체의 적용 & 이벤트 개념, 시간적 측면의 실체 도입 \\
\hline
\end{tabular}


$\mathrm{FRBR}$ 은 완성된 개념 모형이 아니므로 원 리적 측면의 검토 여지가 남아있다. 따라서 위 와 같이 계속적으로 보완 - 확장되고 있지만, 이미 목록계에서는 국제목록원칙규범과 RDA 의 기본 개념이 되어 강력한 영향력을 발휘하 고 있다.

한편, $\mathrm{AACR}$ 과 $\mathrm{MARC}$ 을 사용하는 기존 체 계에서도 FRBR을 구현해 보고자 하는 다양한 각도의 시도가 이루어지고 있다. FRBR은 개 체와 속성, 그리고 그들 간의 관계와 그것을 생 산한 개인/가족/단체에 대한 관계로 이루어져, 각각의 개체가 독립된 레코드로 작성되고 이 들간의 관계로 이루어진 패키지 형태로 인코딩 될 때, 그 사상을 충분히 담아 낼 수 있다고 논 평되고 있다. 그러나 $\mathrm{MARC}$ 을 사용한 기존 인 코딩 방식은 구현형을 중심으로 한 평면 구조 내에서 서지 정보를 표시하고 있을 뿐이다. 이 러한 특징 때문에 지금까지의 거의 모든 FRBR 실현 사례는 $\mathrm{MARC}$ 을 기계적으로 가공할 수 있는 수준에서 처리하여 인터페이스를 개발한 수준에 불과하였다. FRBR을 기반으로 하는 서지적 세계의 실현을 위해서는 (1) FRBR 개 념 모델을 근간으로 접근점 부여 규칙을 포함 한 목록 규칙이 정의되어야 한다. 더불어 (2) 레 코드의 구성과 항목의 설계를 통해 내용적 표 준이 적절하게 표현될 수 있어야 한다. 물론 이 는 교환이 가능한 인코딩 표준으로 설계되어야 할 것이다. 그리고 그 다음이 (3) 이를 관리할 논 리적, 물리적 데이터베이스의 설계와 (4) FRBR OPAC의 구현이다(谷口祥一 2007). FRBR 실현을 위한 수순에 대해 위와 같이 논평한 谷ㅁ 祥一(2007)는 지금까지의 실현 사례는 FRBR 을 흥내 낸 FRBR-Like OPAC이라고 주장하
였다. 그러면서 그는 기존 체계의 전면적 개편 없이는 이러한 구현 수준의 극복이 불가능하다 고 권고한 바 있다.

비슷한 맥락으로, 많은 관계 전문가들은 $\mathrm{RDA}$ 가 FRBR 사상을 충분히 담을 수 있는 내 용적 표준으로 개발되어야 하며, 실제적 구현 을 위해 이를 가장 잘 표현해 줄 수 있는 인코 딩 방식의 설계도 수반되어야 할 것이라고 지 적하고 있다.

\subsection{2 국제목록원칙규범의 재천명}

FRBR은 반세기 동안 존속된 파리원칙(1962) 을 재천명하는데도 동력이 되었다. 목록전문가회 의(IME ICC : IFLA Meetings of Experts on an International Cataloguing Code)를 통해 계 속된 이 개발 작업은 2009년 2월에 최종 발표되 었다. 국제목록원칙규범은 말 그대로 대략의 원 칙이다. RDA와 같이 목록의 실제에 대해 직접 적 영향을 미치지 않지만 목록의 기본 개념에 대한 국제적 합의로써 그 의의를 가진다(渡邊 隆弘 2009). 다음 〈표 3〉은 1960년대의 파리원 칙과 2003년의 초안, 그리고 2009년 2월에 발표 된 완성본에서 포함하고 있는 내용 구성이다. 목록의 요소와 기능으로 FRBR의 개체/속성/ 관계와 태스크를 강조하고 있다는 점, 기술과 접근점의 주요 원칙을 천명하고 있다는 점 등에 서 종전의 원칙과 크게 다르다.

새로운 원칙에서 강조하고 있는 내용의 대략 을 정리해 보면 아래와 같다.

첫 번째, 도서 뿐 아니라 박물관, 기록관 등 의 모든 자료를 포괄한다고 선언하고 있다. 또 한 이용자의 편의, 목록 작성의 경제성과 일관 성, 모든 유형의 자료에 대한 통합성을 일반 원 
〈표 3〉 국제목록원칙규범의 내용 구성

\begin{tabular}{l|l|l}
\hline \multicolumn{1}{c|}{ 파리원칙 } & \multicolumn{1}{|c}{ 초안(2003. 12) } & \multicolumn{1}{|c}{ 완성본(2009. 2)1) } \\
\hline 1. 적용범위 & 1. 적용범위 & 1. 적용범위 \\
2. 목록의 기능 & 2. 개체, 속성, 관계 & 2. 일반 원칙 \\
3. 목록의 구성 & 3. 목록의 기능 & 3. 개체, 속성, 관계 \\
4. 기입의 종류 & 4. 서지 기술 & 4. 목록의 목표와 기능 \\
5. 복수 저록의 사용 & 5. 엑세스 포인트 & 5. 서지 기술 \\
6. 저록의 기능 & 6. 전거 레코드 & 6. 엑세스 포인트 \\
7. 통일 표목의 선택 & 7. 탐색 능력 기반 & 7. 탐색 능력 기반 \\
8. 개인 저작 & & \\
9. 단체 저자 & & \\
10. 복수 저자 & & \\
11. 표제아래 저록이 작성되는 저작 & & \\
12. 개인명에서의 올림말 & & \\
\hline
\end{tabular}

칙으로 하고 있다.

두 번째, FRBR, FRAD, FRSAD(Functional Requirements for Subject Authority Data) 의 개념을 기반으로 개체와 속성, 관계를 정의 하고 있다. 더불어 목록의 기본 기능으로 $\mathrm{FRBR}$ 의 이용자 태스크인 발견, 확인, 선택, 획 득 등을 명시하고 있다.

세 번째, 서지 기술에 있어서는 기존과 같이 구현형을 기준으로 한다. 그러나 단행본의 부 분, 총서와 같이 출판 형태에 따라 구현형이 달 라지는 경우, 종전과 달리 각각을 독립된 기술 로 작성해야 한다고 밝히고 있다.

네 번째, 논란이 많았던 접근점에 대해서는 제어형 접근점과 비제어형 접근점을 모두 포괄 하는 것으로 정리되었다. 제어형 접근점은 서 지레코드의 집중을 위해 필요한 일관성을 제공 하며 전거레코드를 통하여 관리된다고 설명하 고 있다. 여기에는 전거형 뿐만 아니라 이형의 접근점들도 포함된다. 한편, 비제어형 접근점은
구현형의 표제, 부호 등과 같이 서지데이타에 서 제공될 수 있는 정보라고 정의하고 있다.

다섯 번째, 서지레코드와 전거레코드의 필수 접근점을 명시하고 있다. 서지레코드에는 (1) 저작과 표현형에 대한 접근점, (2) 구현형의 표 제, (3) 그리고 저작자명이 필수 접근점이 된다. 그 중 (1) 저작과 표현형에 대한 접근점과 (2) 저 작자명은 전거형을 채택하게 되며, 일반적으로 (3) 구현형의 표제는 비제어형이 된다고 명시하 고 있다. 한편, 전거레코드에서는 전거형과 이 형이 모두 필수 접근점이 된다고 밝히고 있다.

\section{2 $\mathrm{RDA}$ 의 전개 양상}

앞서 기술한 국제목록원칙규범은 FRBR 사 상을 근간으로 하는 국제적 합의로써 새로운 목록 규칙으로 개발되고 있는 $\mathrm{RDA}$ 의 기초가 되었다. 2010년 적용을 목표로 추진되고 있는 $\mathrm{RDA}$ 는 내용적 표준으로서 목록의 실제가 되

1) http://archive.ifla.org/VII/s13/icp/ICP-2009_ko.pdf 
며, 우여곡절 끝에 FRBR 사상과 원칙을 최대 한 수용하게 되었다. 본 장에서는 RDA의 구성 과 특징을 살펴보며, 지금까지의 전개 양상을 정리해 본다.

영국 도서관 - 정보 전문가 협회(CILIP)의 기관지 “Update"를 인용하면, $\mathrm{RDA}$ 의 의의를 아 래와 같이 요약해 볼 수 있다(Chartered Institute of Library and Information Professionals 2008). 로미오와 줄리엣과 같이 합집, 멀티 볼 륨 저작, 번역서 등 다양한 관계의 변화를 가질 수 있는 서지는 AACR2와 MARC으로 다루기 어려웠다. AACR2에는 컨텐츠와 케리어가 혼 재되어 있으나, 하나의 지적 컨텐츠가 다양한 매체로 재생되고 있는 현실의 서지 서계에서는 그 분리가 불가피하게 되었다. $\mathrm{RDA}$ 는 전 세계 적으로 합의된 서지 모형을 기반으로 네트워크 환경에서 모든 유형의 미디어를 효율적으로 통 제하고, 다른 표준과의 상호 운용성을 보장할 수 있는 내용적 표준이다.

JSC는 2007년 10월 회의에서 파트 1을 서지 레코드, 파트 2 를 전거레코드로 구성했었다. 그러나 근본적인 변혁이 불가피한 $\mathrm{RDA}$ 를 $\mathrm{AACR}$ 의 연장선상에서 그리고 있다는 비난이 쏟아졌다. 더불어 기록관, 박물관 등 다른 커뮤 니티와의 제휴라는 핵심 과제를 무시하고 도서 관 커뮤니티에서 자족하고 있다는 지적도 받게 되었다. 따라서 JSC는 FRBR 사상을 기반으로 당초 구조를 크게 변경하게 되었다. 재구성된 구조는 FRBR 개체와 속성, 그리고 그들 간의 관계와 그것을 생산한 개인/가족/단체에 대한 관계로 이루어졌다. 더불어 표현형과 구현형에 대응할 수 있는 컨텐츠와 캐리어의 개념을 강 조하게 되었다. $\mathrm{RDA}$ 의 구성과 내용은 최근 국
내에서도 박진희(2009)에 의해 분석되어 발표 된 바가 있어, 여기에서는 생략하고 RDA가 $\mathrm{AACR}$ 과 크게 달라지는 부분을 정리해 보도 록 한다(Block 2009). 참고로 아직까지 RDA 요소명에 대한 합의된 한국어 용어가 부재하므 로 영문명 그대로를 사용함을 밝힌다.

첫 번째, 접근점의 선택, 표목의 형태, 참조를 강조하고 있는 $\mathrm{AACR}$ 과 달리, $\mathrm{RDA}$ 는 $\mathrm{FRBR}$ 과 $\mathrm{FRAD}$ 의 개체, 속성, 관계를 강조하고 있다. 두 번째, AACR2는 ISBD의 기술 요소를 사 용하고 있으나, RDA는 title, statement of responsibility, edition statement, series statement, carrier type, terms of availability와 같 은 FRBR 개체의 속성을 핵심 요소로 사용하 고 있다.

세 번째, RDA는 자료와 개인/가족/단체간 의 관계, 저작·표현형·구현형·아이템간의 관계, 그리고 개인/가족/단체간의 상호 관계를 강조 하고 있다. 관계에 대한 표현 방식으로 관련 자 료의 식별자 또는 우선 엑세스 포인트 등을 사 용하도록 권고하고 있다.

네 번째, RDA에서는 기본 기입이라는 용어 가 폐기되지만 “저작/표현형의 우선 접근점” 이라는 형태로 그 개념이 유지된다. 저작 레벨 은 "Hemingway, Ernest, 1899-1961. Sun also rises”와 같이 “이름+서명”의 조합으로 표시된 다. 표현형 레벨은 "Brunhoff, Jean de, 18991937. Babar en famile. English. Spoken word" 와 같이 “이름 + 서명 + 언어+내용 타입”으로 표 시된다.

다섯 번째, 컨텐츠와 캐리어의 유형을 강조하 여, 기존의 GMD(General Material Designation) 를 media type(오디오, 비디오, 마이크로폼 등), 
carrier type(필름 릴, 슬라이드 등), content type(카토그래픽, 스틸이미지 등)으로 구분하 고 있다.

여섯 번째, 간행 형태를 다음과 같이 resource issued as a single unit, multipart monograph, serial, integrating resource로 구분하고 있다.

일곱 번째, change in mode of issuance, change in media type, change in edition statement of a serial or integrating resource, re-basing of an integrating resource에 관한 요소를 추가하고 있다. 더불어, first place of publication, title proper of series/subseries, numbering within series/subseries, carrier type은 핵심 요소로 새롭게 정의하고 있다 (Delsey 2009).

여덟 번째, 표목이라는 용어는 더 이상 사용 하지 않고 접근점이라는 용어를 채택하고 있다. 전거형 표목은 'Preferred access point'로, 통일 표제는 'Preferred title'로 변경되며, 그 밖에 아 래〈표 4〉와 같은 용어의 변화가 발생한다.

앞서 말한 바와 같이, JSC는 각계의 협동과 비판 속에서 작업을 계속하고 있으며 조만간 최종안을 발표할 예정이다. 최근 미국 의회 도
서관(LC), 농학 도서관(NAL), 의학 도서관 $(\mathrm{NLM})$ 이 $\mathrm{RDA}$ 의 도입에 관한 공동 선언을 통해 완성에 협조하며, 적용에 관한 평가를 실 시하겠다고 밝힌 바 있다. RDA의 채택으로 인 해 도서관이나 이용자에게 발생할 수 있는 메 리트를 조사하고 직원의 재교육이나 목록 업무 프로세스 재구축과 관련된 비용을 분석하겠다 는 것이다. 2010년 2분기까지 계속될 것으로 보 이는 이 테스트에서는 MARC 21, MODS, DC 등 다양한 레코드로 $\mathrm{RDA}$ 기반 목록을 작성하 게 된다. 공공, 학교, 정부, 대학 도서관 등이 참 여하여 다양한 레벨로 목록 작성을 테스트하게 될 것이다(LC 2009a). 또한 디지털 자원과 아 날로그 자원을 모두 포괄하여 동일 자원을 $\mathrm{AACR}$ 과 RDA 기반으로 작성해 보게 되며, 이 과정에서 무엇이 필요하며 현행 시스템으로 수용되지 않는 부분은 무엇인지가 도출된다 (Bushman 2009). 더불어 하나의 체제로 RDA 와 AACR 기반의 데이터가 공존할 수 있는지 도 파악될 예정이다. 테스트 종료 이후 3 개관 은 도입 여부를 결정하겠다고 밝히고 있다 (Hillmann 2008).

〈표 4〉AACR, RDA 주요 용어 변화

\begin{tabular}{l|l|l|l}
\hline \multicolumn{1}{c|}{ AACR } & \multicolumn{1}{|c|}{ RDA } & \multicolumn{1}{c}{ AACR } & \multicolumn{1}{c}{ RDA } \\
\hline Heading & Access point & Pysical description & Carriers \\
\hline Authorized heading & Preferred access point & Note on the content & Content \\
\hline See references & Variant access point & Main entry & preferred access point \\
\hline Authority control & Access point control & Added entry & Access point \\
\hline Uniform title & Preferred title & Subject Heading & Subject access point \\
\hline Chief source & Preferred source of information & & \\
\hline
\end{tabular}




\section{3. 미래 목록 시나리오 분석}

$\mathrm{JSC}$ 는 RDA 최종안의 검토와 더불어 이를 기반으로 한 미래 목록 시나리오를 제시하고 있다. 세 가지 시나리오를 제시해 FRBR의 실 현과 MARC의 존속이라는 과제를 단계적 수 준에서 담고자 하는 것으로 보여 진다. 본 장에 서는 시나리오 1,2 의 분석을 통해 근접한 서지 제어 체계의 변화 내용을, 그리고 시나리오 3 을 통해서는 장기적 관점에서 변화하게 될 미래의 목록 업무를 살펴보도록 한다.2)

\subsection{RDA 구현을 위한 3가지 시나리오 분석}

시나리오 1,2 는 하나의 싱글 레코드에 $\mathrm{FRBR}$ 그룹 1의 엔티티를 담고 평면적으로 유 지하는 것으로 지금의 구조와 크게 다를 바 없 다. 반면, 시나리오 3 은 FRBR 엔티티를 반영
하는 복수개의 독립된 레코드를 유지하고 이들 을 식별자로 연계하는 구조이다(The Joint Steering Committee for Development of RDA 2007). 시나리오 1 부터 자세히 살펴보도 록 한다.

\subsection{1 시나리오 1 : 평면적 구조}

시나리오 1 은 〈그림 1 〉과 같이 로컬 소장 정 보를 포함한 거의 모든 데이터 요소를 서지레 코드가 가지고 있는 구조로, 전통적 전거 제어 체계를 따른다. 현행의 MARC과 유사한 평면 적 구조를 가지는 시나리오 1 을 좀 더 구체적으 로 살펴본다.

첫 번째, 서지레코드에 AACR의 Main entry 에 해당하는 Preferred name, Preferred title, 그 밖에 role, language 요소가 정의되어 있는 데, 이들 요소가 FRBR의 “저작 또는 표현형 레벨의 식별”이라는 개념에 대응되고 있다. 한

\begin{tabular}{|c|c|}
\hline Bibliographic record & Name - Title Authority record \\
\hline $\left.\begin{array}{l}\text { Preferred name } \\
\text { Preferred title } \\
\text { role, language }\end{array}\right\}$ & $\begin{array}{l}\text { Preferred name } \\
\text { \{Preferred title } \\
\text { Related work }\end{array}$ \\
\hline Nature and scope of content & \\
\hline Title proper & Name Authority record \\
\hline Publisher & Preferred name \\
\hline $\begin{array}{l}\text { Item-specific carrier characteristics } \\
\text { Provenance }\end{array}$ & Related person \\
\hline Related work: preferred title & \\
\hline
\end{tabular}

〈그림 1〉시나리오 1

2) JCS에서는 시나리오 1 을 FRBR 엔티티를 기반으로 하는 구조로 제안하고 시나리오 2, 3을 현행 구조를 기반으 로 하는 안으로 제시하였으나, 본 고에서는 편의상 그 순서를 바꿔서 설명한다. 
편, 다양한 매체의 수용을 위해 새롭게 고안된 Nature and scope of content 그리고 Carrier type의 일부 요소가 존재하는데, 이들 요소는 “저작과 표현형 레벨의 선택”을 위해 활용된다. 더불어 유관 저작을 연계시키기 위한 요소로 Related work : preferred title이 정의되어 있다.

두 번째, 역시 서지레코드에 기술 요소로서 Title proper, Statement of responsibility, Publisher 등이 정의되어 있다. 이들 요소는 대 부분 FRBR의 구현형 레벨에 대응된다. 한편, Item-specific carrier characteristics, Provenance, Restriction on access 등의 요소는 “아이템 레벨의 식별, 선택, 획득”을 위해 사용 된다.

세 번째, 이 시나리오는 전형적인 전거제어 시스템의 전통을 고수하고 있다. 따라서 필수 접근점들은 대부분 제어형 접근점을 채택하고 있다.

한편, 또한 주목할 것은 “이름-서명 전거 레
코드"의 기능이 매우 강조되고 있다는 점이다. 국내 전거 관행으로 다소 생소한 개념이지만, “이름-서명 전거레코드”는 이미 OCLC FRBR work-set 알고리즘에서도 저작 레벨의 클러스 터 형성을 위한 핵심 도구로 활용된 바 있다. 저작과 표현형을 식별하며, 동일 저작에서 파 생된 유관 저작을 논리적으로 집중시키기 위한 핵심 기능을 수행하는 "이름-서명 전거레코드" 는 시나리오 1 과 다음에서 제시할 시나리오 2 에서도 강조되고 있다.

\subsection{2 시나리오 $2:$ 서지/전거 레코드의 구조적 연계}

시나리오 2 는 시나리오 1 에서 전술한 내용과 특징을 기반으로 하지만 서지와 전거레코드가 구조적으로 연계되며, 더불어 전거 레코드간의 연계를 통해 개인과 개인, 단체와 단체 등의 관 계가 관리된다는 점에서 차이가 있다.

시나리오 2 의 특징을 정리해 보면 다음과 같다.

Bibliographic record

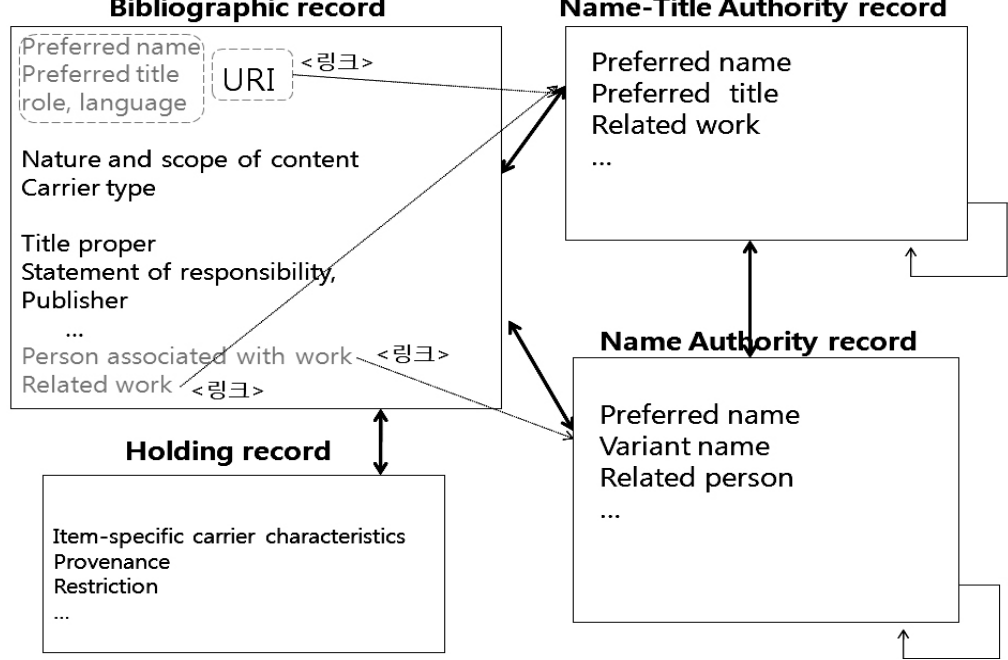

〈그림 2〉시나리오 2 
첫 번째, 이름-서명 전거레코드는 “저작과 표현형의 식별”에 해당하는 Preferred name, Preferred title 등의 요소를 주로 포함하고 있 다. 또한 여기에 저작 간의 관계를 처리할 수 있는 속성으로 Related work가 정의되어 있어, 이를 기반으로 유관 저작이 구조적으로 연계될 수 있다.

두 번째, 서지레코드에는 구현형에 대응되는 Title proper, Statement of responsibility, Publisher 등의 요소를 주로 포함하고 있다. 그 러나 “저작과 표현형 레벨의 선택”을 위한 Nature and scope of content 그리고 Carrier type의 일부 요소도 여기에 포함되어 있다.

세 번째, 소장레코드는 Item-specific carrier characteristics, Provenance, Restriction on access 관련 요소를 포함하고 있으며, 시나리오 1 과 달리 독립된 파일로 관리된다.

네 번째, 서지레코드와 전거레코드는 구조적 으로 연계되어 있다. 서지레코드에는 주로 기 술 요소가 관리되며, 각종 접근점들은 구조적 으로 연계되어 있는 전거레코드를 통해 관리된 다. 시나리오 1 에서 채택하고 있는 전통적 전거 제어 체계와 차이를 갖고 있는 이 방식은 고유 식별자를 통해 서지와 전거, 전거와 전거가 연 계될 수 있다고 설명되어 있다. 한편, 이름 전거 레코드 간의 구조적 연계를 통해서 개인과 개 인, 단체와 단체 등과의 관계를 관리할 수 있게 된다. 시나리오 1 에서와 마찬가지로 "저작과 표현형의 식별”과 유관 저작의 효과적 탐색을 위해 이름-서명 전거레코드가 주요한 기능을 담당하고 있다.
MARBI(Machine-Readable Bibliographic Information Committee)는 MARC을 가지고 2 번째 시나리오를 구현하기 위하여 작업 중이 라고 한다. 자세한 내용은 3.2장 MARC의 변 용을 통한 시나리오 2 의 구현 부분에서 자세히 살펴보도록 한다.

3.1.3 시나리오 3 : 관계/객체 지향형 구조 시나리오 3 은 FRBR 엔티티에 근거한 관계/ 객체지향형 데이터베이스 구조이다. 주요 기술 요소는 FRBR의 그룹 1 엔티티를 반영하고 있 으며 접근점은 $\mathrm{FRAD}$ 모델에 의해 전거레코드 에서 관리한다. 객체간의 관계는 $\mathrm{FRBR}$ 의 관 계를 반영하고 있으며 개인/단체/조직간의 관 계도 전거에 반영되어 있다. 이 모델은 $\mathrm{FRBR}$ 의 개념을 가장 성실하게 반영하고 있지만, 현 행 인코딩 방식과 ILS가 수용하기 어려운 모델 로 평가받고 있다.3)

이 시나리오의 특징을 정리해 보면 아래와 같다.

첫 번째, 저작 레코드에는 Preferred title, Preferred name 등과 같이 “저작의 식별”에 관한 정보 이외에도 “저작의 선택”을 위한 요 소로 Nature and scope of content를 포함하고 있다. 더불어 유관 저작의 연계를 위한 요소로 Related work를 포함하고 있어, 저작 레벨에서 또 다른 유관 저작 레벨로 연계될 수 있다.

두 번째, 저작 레코드는 표현형 레코드와 "realized through"의 관계를 형성하며, 구현형 레코드와는 "embodies"라는 관계 유형을 형성 한다.

3) LC, 2008, "Encoding RDA, Resource Description and Access data in MARC 21", MARC DISCUSSION PAPER NO. 2008-DP04, [cited 2008. 12.12].〈http://www.loc.gov/marc/marbi/2008/2008-dp04.html〉. 


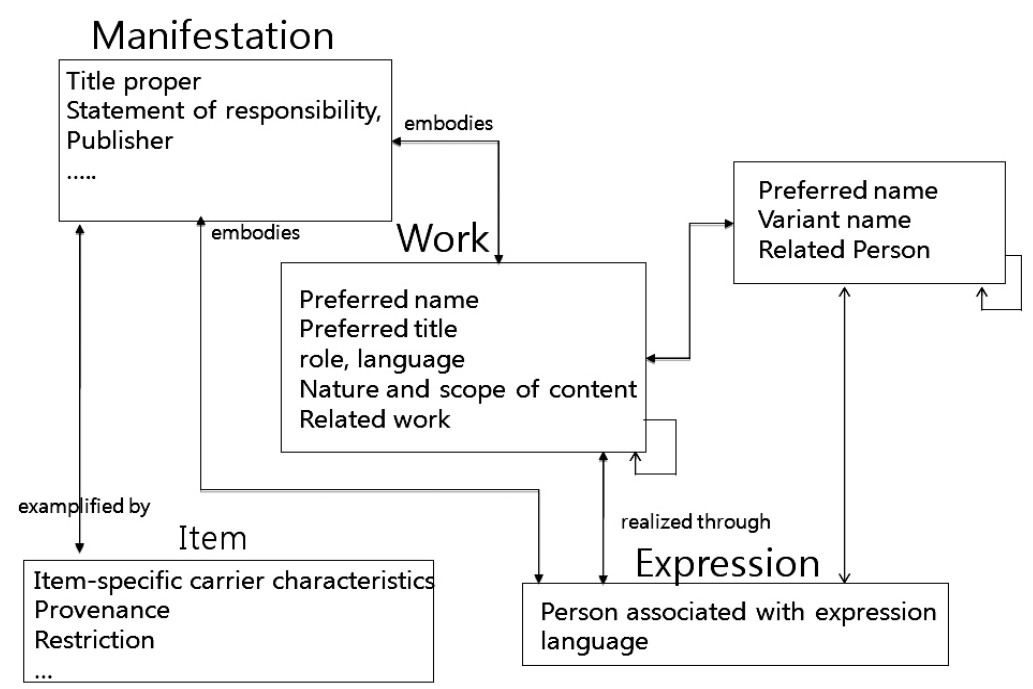

〈그림 3〉시나리오 3

세 번째, 시나리오 1,2 에서 분산되어 있는 표현형 관련 요소들이 별도의 레코드로 형성되 어 관리된다.

네 번째, 구현형 레코드에는 Title proper, Statement of responsibility, Publisher 등의 기 술 요소가 정의되어 있으며, 저작 및 표현형 레코 드와는 "embodies"라는 관계 유형을 형성한다.

다섯 번째, 아이템 레코드에는 Item-specific carrier characteristics, Provenance, Restriction on access 등의 로컬 소장 정보가 정의되어 있으며 구현형과는 "examplified by"의 관계를 갖는다.

다섯 번째, 각종 접근점은 전거 레코드에서 관 리되며, 따라서 저작과 표현형 레코드에는 전거로 연계시킬 수 있는 링크 정보를 관리하게 된다.

DCMI/RDA Task Force의 의장인 Hillmann
(2008)은 개체의 관계와 역할을 강조하는 서지 데이타 구조화에 적합한 모델은 오직 시나리오 3 뿐이라고 지적하였다. 그는 시나리오 3 을 기 반으로 한 미래 목록 업무 플로우를 제시한 바 있는데, 다음 〈그림 4〉를 통해 간단하게 설명해 본다.

그는 시멘틱 웹 구조를 사용하게 될 장래의 서지제어 작업은 기계 친화적 링크를 사용하게 되어, 사서의 주석과 텍스트 스트링 의존은 매 우 감소하게 될 것이라고 전망하였다. 그리고 저자명, 출판사명, 언어, 컨텐츠의 유형과 같은 속성은 고유 식별자를 통해 관리될 것이라고 덧붙였다. DCMI/RDA Task Force는 이미 메 타데이터 레지스트리에 RDA 요소, 역할, 어휘 를 등록하고4) 있다고 설명하면서, 장기적으로

4) RDA Elements : 〈http://metadataregistry.org/schema/show/id/1.html〉

RDA Roles : 〈http://metadataregistry.org/schema/show/id/4.html〉

RDA Vocabulary: Base Material : 〈http://metadataregistry.org/vocabulary/show/id/35.html〉

FRBR Relationships (Sandbox version) : 〈http://sandbox.metadataregistry〉 
1) 목록자가 kurt Vomnegut의 라트비안 번역본을 목록 할 경 우, 먼저 기 구축된 work 데이 터를 검색

※ 해당 work 데이터는 이미 표현 형 데이터와 구현형 데이터가 링크되어 있을 수 있음

2) 목록자는 기존의 work에 표현 형 요소를 기술하여 별도의 엔 티티를 만들어 work에 링크 시킴

3) 새로운 구현형 정보를 기술함. 출판사 전거가 기구축되어 있 다면 연계하며, 표현형에 번역 자의 전거가 부재하다면 번역 자 전거를 새로 작성.

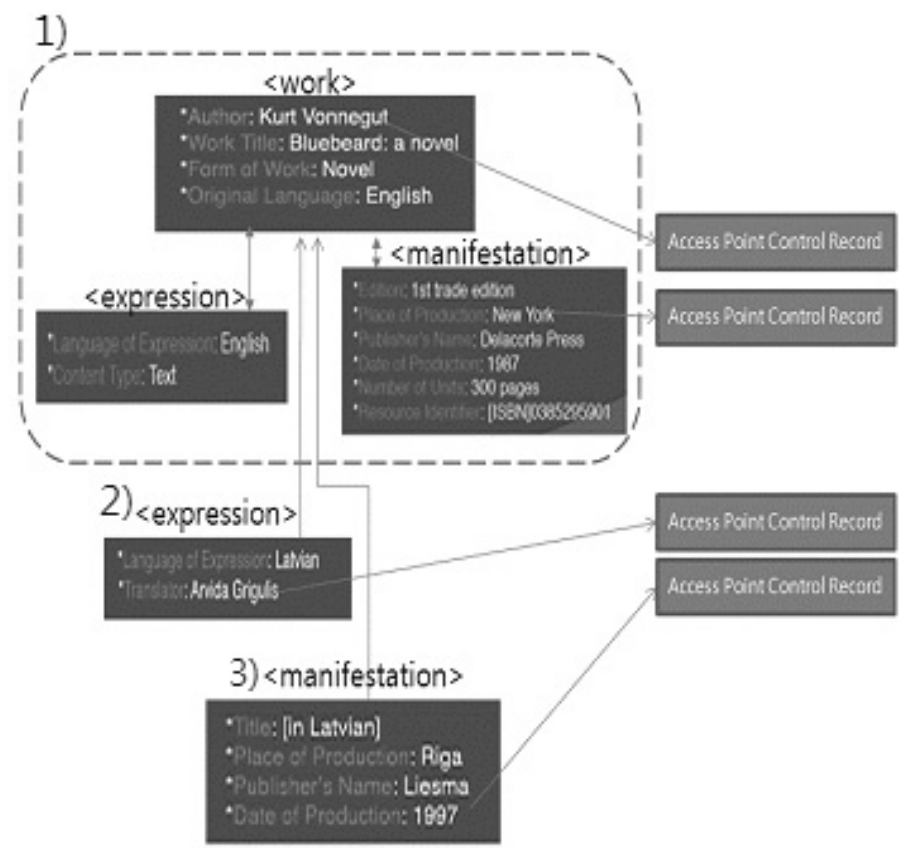

〈그림 4〉시나리오 3에 입각한 목록 업무 플로우
는 시멘틱 웹 기반의 도구와 MARC-RDA(시 나리오 3 기반) 전환 솔루션의 개발이 필요할 것이라고 논평하였다.

\subsection{4 시나리오 분석}

세 가지 시나리오에 따른 FRBR 그룹 1 엔 티티의 레코드 속성을 다음 〈표 5〉와 같이 정리 하였다. 시나리오 3에서는 저작, 표현형, 구현 형, 아이템의 엔티티가 각각 독립된 레코드로 설계된다. 반면, 현행 서지 구조를 기반으로 하 는 시나리오 1 과 2에서는 "저작과 표현형의 식 별”을 이름-서명 전거레코드로, “저작과 표현 형의 선택”과 “구현형”을 서지레코드로 표현
하고 있다. 시나리오 1 이 전통적 전거 제어 방 식을 채택하고 있는 반면, 시나리오 2는 서지와 전거를 구조적으로 연계시키고 있다는 점에서 차이가 있다. 더불어 평면적 구조를 가지고 있 는 시나리오 1 에서는 아이템 레벨의 요소를 서 지레코드에 포함시키고 있는 반면, 시나리오 2 에서는 이 요소들을 모두 소장레코드로 분리시 키고 있다. 그러나 여하튼 이 두 가지 모델은 모두 전거 통제를 강조하고 있으며, 특히 저작 과 표현형의 식별을 위한 '이름-서명 전거레코 드'의 기능을 강조하고 있다는 점을 주목해야 하겠다. 
〈표 5〉세 가지 시나리오에 따른 FRBR 그룹 1엔티티의 레코드 속성 (The Joint Steering Committee for Development of RDA 2008)

\begin{tabular}{|c|c|c|c|c|}
\hline \multirow{2}{*}{$\begin{array}{l}\text { FRBR 그룹 1엔 } \\
\text { 티티 }\end{array}$} & \multirow{2}{*}{$\begin{array}{l}\text { 이용자 } \\
\text { 태스크 }\end{array}$} & \multicolumn{3}{|c|}{ JSC의 세가지 시나리오 } \\
\hline & & 1 & 2 & 3 \\
\hline \multirow{2}{*}{ 저작 } & 식별 & \multicolumn{2}{|c|}{ 이름-서명 전거레코드(1XX, 4XX, 687-680) } & \multirow{2}{*}{$\begin{array}{l}\text { 저작 } \\
\text { 레코드 }\end{array}$} \\
\hline & 선택 & 서지레코드(5XX) & & \\
\hline \multirow{2}{*}{ 표현형 } & 식별 & \multicolumn{2}{|c|}{ 이름-서명 전거레코드(1XX, 4XX, 687-680) } & \multirow{2}{*}{ 표현형 레코드 } \\
\hline & 선택 & \multicolumn{2}{|c|}{ 서지레코드(5XX) } & \\
\hline \multirow{3}{*}{ 구현형 } & 식별 & \multicolumn{2}{|c|}{ 서지레코드(2XX, 310,321,362,4XX,5XX) } & \multirow{3}{*}{ 구현형 레코드 } \\
\hline & 선택 & \multicolumn{2}{|c|}{ 서지레코드 $(300,340,5 X X)$} & \\
\hline & 획득 & \multicolumn{2}{|l|}{ 서지레코드 $(352,355,5 \mathrm{XX})$} & \\
\hline \multirow{3}{*}{ 아이템 } & 식별 & 서지레코드(5XX) & $\begin{array}{l}\text { 서지레코드(5XX) } \\
\text { 소장레코드(5XX) }\end{array}$ & \multirow{3}{*}{ 아이템 레코드 } \\
\hline & 선택 & 서지레코드(5XX) & $\begin{array}{l}\text { 서지레코드(5XX) } \\
\text { 소장레코드(5XX) }\end{array}$ & \\
\hline & 획득 & 서지레코드(5XX, 850-856) & $\begin{array}{l}\text { 서지레코드(5XX, 850-856) } \\
\text { 소장레코드(5XX, 852-856) }\end{array}$ & \\
\hline
\end{tabular}

$\mathrm{JSC}$ 가 제시한 3 가지 시나리오 중 1 과 2는 현행 인코딩 방식을 이용하여 표현이 가능하다 는 측면에서 근접한 미래에 채택될 가능성이 있다. 언급했다시피, MARBI는 MARC을 변 용하여 시나리오 2 를 구현하기 위한 작업을 진 행 중이다. 이상적인 서지적 세계를 나타내고 있는 시나리오 3 은 당장 도서관 현장에 채택되 기 어려워 보이지만 시나리오 3 을 위한 교환용 인코딩 방식과 기존 데이터 변환 프로그램 개 발, 그리고 ILS 시스템의 개편을 위한 준비도 병행되어야 할 것으로 보여 진다. 한편, 2009 년 6월 ALA Annual 미팅에서 이미 VTLS (Visionary Technology in Library Solutions) 는 차세대 목록 시스템의 데모 버전(Espley, 2009)을 선보인 바 있는데, 시나리오 3에 입각 하고 있어, 주목해 볼 만하다.

\subsection{MARC의 변용을 통한 시나리오 2의 구현}

$\mathrm{RDA}$ 는 언급했다시피, 당초 구조가 크게 개 편되어, $\mathrm{FRBR}$ 을 수용하는 내용적 표준으로 개발되고 있다. 그러나 RDA의 실제 구현을 위 하여 인코딩 방식을 결정하는 과정에 있어서는 보수적 입장이 견지되고 있다. JSC는 수 천만 건의 MARC 기반 소급 데이타와 기존 ILS 시 스템에 대한 현장의 목소리를 외면하기 어렵다 는 입장을 보이고 있다. 비록 위에서 살펴본 바 와 같이, 복수개의 구현 시나리오가 제시되기 는 하였지만, 그 중 MARC을 존속시킬 수 있 는 구현 시나리오에 대한 채택 가능성이 높아 졌으며, 이에 따라 새로운 필드의 추가와 부분 적 변경을 통해 MARC21로 RDA를 적용하기 위한 가이드라인이 개발되게 되었다. JSC는 새 로운 필드의 고안을 비롯해 몇 가지 부분의 수 정은 필요하겠지만, $\mathrm{RDA}$ 요소가 $\mathrm{MARC}$ 과 대 
〈표 6〉RDA 구현을 위해 MARC21 포맷이 변경되는 주요 내용(진행 중)

\begin{tabular}{|c|c|c|c|}
\hline \multicolumn{2}{|c|}{ 구 분 } & \multicolumn{2}{|c|}{ 필 드 } \\
\hline \multirow{3}{*}{$\begin{array}{l}\text { 새로운 } \\
\text { 필드 }\end{array}$} & 서지레코드 & \multicolumn{2}{|c|}{$\begin{array}{l}011 \text { FRBR의 엔티티 표시 ( \$aexpression \$2rda) } \\
336 \text { Content type } \\
337 \text { Media type } \\
338 \text { Carrier type }\end{array}$} \\
\hline & 전거레코드 & $\begin{array}{ll}046 & \text { Special coded dates } \\
336 & \text { Content Type } \\
370 & \text { Associated Place } \\
371 & \text { Address } \\
372 & \text { Field of Activity }\end{array}$ & $\begin{array}{ll}373 & \text { Affiliation } \\
374 & \text { Occupation } \\
375 & \text { Gender } \\
376 & \text { Family Information } \\
377 & \text { Associated Language }\end{array}$ \\
\hline & 소장레코드 & $\begin{array}{l}337 \text { - Media Type } \\
338 \text { - Carrier Type }\end{array}$ & \\
\hline \multirow{2}{*}{\multicolumn{2}{|c|}{$\begin{array}{l}\text { 고정장의 } \\
\text { 변경 }\end{array}$}} & \multicolumn{2}{|c|}{\begin{tabular}{l|ll}
\multirow{2}{*}{007} & $\begin{array}{l}007 / 01 \\
007 / 04\end{array}$ (Primary support material) v,w,n,i,l
\end{tabular}} \\
\hline & & \multicolumn{2}{|c|}{008 008/20 (Format of music) h,i,j } \\
\hline
\end{tabular}

부분 상응되기 때문에, 큰 변화가 필요하지 않 을 것이라고 말하였다. 핵심은 다음과 같다. 저 작과 표현형은 이름-서명 전거레코드가 맡고, 구현형은 서지레코드가 맡아 시나리오 2를 구 현한다는 것이다. 올 초 회의 자료를 보면, 서지 레코드 1XX, 240/130 태그의 접근점들은 "저 작과 표현형의 식별”을 위해 사용하며, URI 링 크를 통해 전거레코드와 연계시키거나, 전거형 의 채택을 통한 연계를 제안할 예정이라고 하 였다(LC 2009b). 대안적으로 저작과 표현형을 독립된 서지레코드로 표현하는 방식도 제안할 예정이라고 한다.

한편, $\mathrm{GMD}, \mathrm{SMD}$ 는 변경이 불가피한데, 변 경된 부분을 수용하기 위하여 목록시스템은 부 분적으로 재설계할 필요가 있을 것이라고 하였 다. 더불어 엑세스 포인트의 변경 때문에 데이 터의 소급 변화가 필요할 수도 있을 것이라고 밝히고 있다. 아직 작업이 진행 중이지만, 최근 발표된 자료를 통해 MARC 포맷에서 변경되 는 주요 내용을 위의 〈표 6 〉과 같이 살펴 볼 수
있다(MARBI, 2009).

\section{4. 해외 주요 서지기관의 반응과 대응}

새로운 목록 규칙의 구현 방식에 대하여 현 실적 대응이라는 비판에서부터 개혁의 의미가 없다는 지적까지 나오고 있다. 서지 기관들은 이러한 상황을 예의 주시하고 있으며, 최종 발 표가 나오기를 기다리고 있다. 여기에서는 해 외 주요 서지 기관의 반응과 대응 방향을 살펴 보도록 한다.

$\mathrm{LC}$ 는 40여년전에 개발된 MARC 포맷은 현 대 자원에 대한 기술에 적합하지 않다고 말하 며, 앞으로는 Web에 적합한 시스템 규격으로 대응하겠다고 입장을 밝힌 바 있다. 더불어 비 공식적 소식에 의하면, 2010년 이후 더 이상 MARC 21을 사용하지 않을 수 있다고 언급했 다고 한다(Hillmann 2008). LC는 RDA 채택 
메리트가 현재로서 눈에 띄지 않는다고 말하고, $\mathrm{JSC}$ 가 RDA 개발을 일지 중지할 필요가 있다 고 권고한 바도 있다. 더불어 도서관이외의 커뮤니티에서 사용되는 메타데이터와의 상호 운용을 위해 DCMI(Dublin Core Metadata Initiative) 와의 협동 작업을 권고하기도 하였 다. 비록 $\mathrm{LC}$ 는 RDA의 완성과 테스트에 협조 하고 있기는 하지만, 여러 정황으로 보아, 현재 진행 중인 각종 원칙 및 규칙의 전개 양상에 다 소간 회의적 입장을 가지고 있는 것처럼 보인 다. $\mathrm{LC}$ 는 일단은 $\mathrm{RDA}$ 전개 상황을 주목하지 만, 채택 여부와 무관한 독자적 생존 전략도 마 련하고 있는데, 주요 골자를 정리하면 다음과 같다(Working Group on the Future of Bibliographic Contro 2008). 첫 번째는 도서관 과 관련된 모든 유형의 자원을 효과적으로 표 현하고 상호 운용될 수 있도록 하는 미래지향 적 메타 데이타를 개발 - 운영한다는 것이다. 더불어 데이터의 요소와 어휘를 위한 웹기반 식별자를 운영하겠다고 하였다. 두 번째, 서지 시스템에서 FRBR을 실현할 수 있도록 스키마 를 개발하고 시스템 벤더들과 필요한 사항을 합의한다는 것이다. 더불어 관련 실험과 연구 를 지속적으로 수행하겠다고 하였다. 세 번째 는 목록 작성 작업의 경제적 효용성에 대해 반 성하고 그 체계를 개선하겠다는 것이다. 출판 유통의 공급사슬상에 생성된 메타 데이타를 통 해 데이터의 재활용성을 제고하고, 공동목록 활성화를 통해 서지와 전거 레코드 작성·유지 면에서의 책임을 분산시키겠다는 것이다. 그 밖에 주제명 표목의 최적화와 희귀본, 유일본
및 기타 특수 미공개 자료에 대한 접근성을 높 인다는 내용 등이 포함되어 있다.

한편, 일본도서관협회 목록위원회는 현행 일 본목록규칙 $(\mathrm{NCR})$ 은 차세대 목록 원칙 및 규 칙과 근본적 개념 차이를 가지고 있다고 하였 다. 목록위원회는 서지와 전거 데이터를 새로 운 형식으로 제공할 필요가 있다고 생각하고 있으며, NDLSH(國立國會図書館件名標目表 : National Diet Library List of Subject Headings) 도 SKOS(Simple Knowledge Organization System) 형식으로 표현해 시멘틱 웹 환경에서 제공하는 것을 검토하고 있다고 밝히고 있다. 더불어 비기본기입제를 채택하고 있는 현행 $\mathrm{NCR}$ 구조는 $\mathrm{FRBR}$ 개념과 근본적 인 차이가 있기 때문에, RDA 채택 여부와 무 관하게 개정을 계획하고 있다고 말하였다. 일 본국립국회도서관도 NDL의 서지데이터 뿐 아 니라, 일본 전체의 서지데이터가 어떤 대응을 해야 할지에 대해 진지하게 고민하고 있다고 밝혔다. 더불어 $\mathrm{FRBR}$ 과 $\mathrm{RDA}$ 동향을 주목하 면서 도서관협회와 목록규칙개정 작업을 진행 하고, MARC 형식을 재검토하는 등 서지데이 타의 새로운 개념 모델과 표준에 대응하겠다고 발표하였다(中井万知子, 2008).

한편, 호주 국립도서관은 최근 발표를 통해 자국내 도서관의 $\mathrm{RDA}$ 데이터 생성과 교환, $\mathrm{AACR}$ 데이터의 변환을 지원하겠다고 밝혔다. 더불어 $\mathrm{RDA}$ 기반 데이타와 $\mathrm{AACR}$ 기반 데이 터의 시스템적 공존이 가능하도록 지원하겠다 고 덧붙였다. 호주 도서관 대부분에 수요가 발 생하게 되면, Library Austrailia5) 데이터에

5) 호주 국립중앙도서관이 운영하는 국가종합목록 
대한 전체적 변환을 계획하고 있으며, 사전에 실무자들에게 $\mathrm{RDA}$ 적용을 위한 충분한 교육 을 할 것이라고 발표하였다. 한편, OCLC(Online Computer Library Center)는 아직까지 WorldCat 의 RDA 구현에 대하여 공식적인 발표는 없다. 그러나 JSC RDA Examples Groups, RDA/ MARC Working Group 등에서 활동하며, RDA 개발의 조력자로서 역할을 하고 있다. 최종 발 표가 이루어지면 WorldCat 적용 여부에 대해 입장을 발표하겠다고 한다(Libraries Australia 2008).

\section{5. 한국 서지 제어 체계의 대응 과제}

본 고에서는 서지 제어를 둘러싼 각종 원칙 과 표준 체계 개정 동향에 대하여 살펴보고, $\mathrm{FRBR}$ 과 RDA를 기반으로 논의되고 있는 미 래의 목록 업무 시나리오를 분석해 보았다. 더 불어 이러한 현상에 대해 주요 서지 기관들은 어떻게 반응하고 있으며, 어떠한 방침으로 대 응하고 있는지 살펴보았다. 본 장에서는 우리 나라의 서지 제어 체계가 글로벌 환경 변화에 대응하기 위해 필요한 몇 가지 과제에 대해 논 해 보고자 한다.

1) $\mathrm{RDA}, \mathrm{FRBR}$ 과 $\mathrm{KCR}($ Korean Cataloging Rule : 한국목록규칙)의 관계 검토 개체와 관계를 기반으로 하는 RDA와 현행 목록규칙인 $\mathrm{KCR}$ 은 근본적 사고에서부터 큰 차이를 지닌다. RDA가 최종 발표되면 $\mathrm{KCR}$ 과 의 매핑이 요구되겠지만, 그에 앞서 목록계는 좀 더 근원적 차원의 검토를 선행하는 것이 바
람직할 것이다. 목록에 대한 국제적 합의인 국 제목록원칙규범이 재천명된 만큼 여기에 담고 있는 철학과 개념을 $\mathrm{KCR}$ 이 실현할 수 있는지 살펴봐야 할 것이다. $\mathrm{RDA}$ 를 그대로 수용할 것 인지, $\mathrm{KCR}$ 을 독자적으로 발전시킬 것인지에 대한 판단과 고민도 요구된다. 한편, $\mathrm{FRBR}$ 은 국제목록원칙규범과 RDA가 근간으로 하고 있 는 매우 영향력 있는 개념이긴 하지만, 완성된 모델은 아니며, 아직까지 원리적 부분의 검토 여지가 남아 있다. FRBR의 이론적·응용적 연구와 한국적 수용을 위한 다각적 검토가 병 행되어야 할 것이다.

2) $\mathrm{RDA}$ 적용 평가와 준비

$\mathrm{RDA}$ 테스트 결과가 2010년 중에 발표될 예 정이다. 언급한 바와 같이 $\mathrm{RDA}$ 채택에 따른 혜택과 비용, 목록 업무 프로세스 재구축 여부, 시스템 개선 요구 사항 및 데이타의 소급 변환 필요성 등이 평가될 예정이다. 평가 결과를 예 의 주시해야 할 뿐 아니라, 국내 상황에 맞춰 재해석하고 필요에 따라 독자적인 평가 계획을 추진할 필요도 있을 것이다. 더불어 $\mathrm{RDA}$ 의 수 용 여부와 구현 수준도 결정해야 할 것이다. $\mathrm{RDA}$ 의 수용이 결정되면, 국가 서지 기관은 데 이터의 소급 변환과 실무 수준의 교육 프로그 램을 실시하고 ILS의 변경이 요구되는 경우, 벤더를 위한 가이드라인을 마련해야 할 것이다.

3) KORMRC에 대한 근본적 검토

FRBR의 충실한 구현을 위해서는 인코딩 방 법이 변경되어야 한다. JSC는 소급 데이타를 고려하여 MARC21과 대응 가능한 시나리오를 제안하였으나, 많은 비판을 받고 있으며, $\mathrm{LC}$ 는 
어느 시점부터는 더 이상 MARC21을 사용하 지 않을 것이라고 언급한 바도 있다. 당장은 변 용된 $\mathrm{MARC}$ 을 통해 $\mathrm{RDA}$ 를 표현하겠지만 불 가피한 과도기가 생각보다 짧게 지나갈 수도 있을 것이다. 따라서 국가 서지 기관을 비롯한 목록계에서는 장기적 관점으로 미래의 목록 업 무를 예측하고 그에 부합하는 인코딩 방식에 대해 고민할 필요가 있을 것이다.

4) 전거 통제에 대한 실질적 대책

안영희와 이성숙(2009)의 논문에서 제기된 바와 같이 $\mathrm{FRAD}$ 와 RDA, KORMARC과의 관계를 검토하고 전거 제어와 관련된 규칙과 방식이 마련되어야 한다. 더구나 이 부분을 연 구할 때, JSC가 '저작과 표현형의 식별'을 위해 사용을 권고하고 있는 이름-서명 전거레코드의 문제를 함께 고민해야 할 것이다. 우리나라 도 서관에서는 이름-서명 전거레코드가 구축되지 않고 있으며, 실무자들에게 그 개념조차 낮설 다. 새로운 원칙과 규칙의 구현에 있어 이름-서 명 전거레코드가 가지게 될 기능과 의미를 검 토해 보고 적절한 대안을 모색할 필요가 있다. 그에 앞서, 국가 서지 기관은 이름 전거레코드 조차 구축과 활용이 미비한 도서관 현장의 현 주소를 다각적으로 점검해 보고, 효율적 구축 과 보급, 공동 활용을 위한 전략 수립을 무엇보 다 시급한 과제로 추진해야 할 것이다.

5) 새로운 규칙과 원칙에 대한 관련 커뮤니티 이해 제고 및 다각적 지원

도서관 현장의 목록 사서, 시스템 개발 벤더 들이 새로운 목록 규칙과 원칙에 대한 이해를 제고할 수 있도록 지원이 필요할 것이다. 대폭
변경된 $\mathrm{AACR}$ 의 용어에 대한 한국어 용어의 결정과 각종 자료의 번역과 요약, 그리고 다양 한 수준의 교육 프로그램이 개발되어야 할 것 이다. 더불어, $\mathrm{RDA}$ 데이터의 생성과 교환, $\mathrm{KCR} / \mathrm{AACR}$ 데이터의 변환과 시스템적 공존 을 위한 지원도 고려되어야 할 것이다.

6) 목록 작성의 경제성 및 활용성 제고 목록 표준을 위한 과제와 다소 동떨어져 있 으나, 새로운 국제목록원칙규범에서는 목록 작성의 경제성과 활용성 제고가 매우 중요한 과제로 강조되고 있다. 더불어 이는 모든 서지 제어 기관의 가장 현실인 과제 중 하나일 것이 다. 검색 엔진과 대비하여 현저하게 떨어지는 목록 작성 작업의 경제성을 제고하기 위하여, 공동 목록을 활성화하고 $\mathrm{CIP}$ (Cataloging in Publication)를 제도화하며, 출판물의 공급사슬 상에서 발생된 각종 메타데이터를 효과적으로 재활용하는 방안을 고민할 필요가 있을 것이다.

7) 미래의 서지 제어를 위한 연구 지원 체계 $\mathrm{RDA}$ 의 한국적 구현, 인코딩 포맷의 보완, 기구축 데이터 및 시스템의 변환, 업무 프로세 스의 재구축, 전거제어의 규칙과 방식의 마련 등 이 분야에는 시급한 연구 주제가 산적해 있 다. 관련 연구 결과가 매우 제한적으로 발표되 고 있는 상황에서 한국적 상황에 접합시킬 수 있는 대안적 연구의 지원 및 독려가 필요하다 고 본다.

\section{8) 목록의 교육 내용 개선}

목록의 위기시대에 목록 사서의 역할을 재정 립하고 그에 부합하는 인재가 양성될 수 있도 
록 교육 체계의 개선이 필요하다. JSC(2009) 가 권고하는 있는 바와 같이, FRBR 개념을 포 함하여, 새로운 각도에서 목록의 원칙과 기능 에 대한 교육이 이루어져야 할 것이다. 메타 데
이타의 세계에서 도서관 목록이 차지하는 위치, 다른 메타 데이타와의 관계와 상호 운용성을 충분히 이해하고 응용할 수 있도록 교육이 이 루어져야 할 것이다.

\section{참 고 문 헌}

[1] 古川肇. 2009. “RDA 全体草案とその前後.”カレントアウェアネス, No.299. 2009年3月20日. [online]. [cited 2009. 6.7]. 〈http://current.ndl.go.jp/ca1686〉.

[2] 谷口祥一. 2007. “FRBR のその後：FRBR 目錄規則？FRBR OPAC.” [online]. [cited 2009. 3.10]. 〈http://www.slis.tsukuba.ac.jp/ taniguch/TP\&Dforum2007.pdf〉.

[3] 渡邊隆弘. 2008. “FRBR のとらえる「書誌的世界」FRBROO を中心に.”情報組織化研究 グループ月例研究會. 2008.3.15. [online]. [cited 2009.4.10].

〈http://www.tezuka-gu.ac.jp/public/seiken/meeting/2008/watanabe20080315.pdf〉.

[4]渡邊隆弘. 2009.“IFLA「國際目錄原則」をめぐって”情報組織化研究. 2009.4.18. [online]. [cited 2009.6].

〈http://www.tezuka-gu.ac.jp/public/seiken/meeting/2009/watanabe20090418.pdf〉.

[5] 박진희. 2009. RDA의 제정동향 및 내용구조에 관한 연구. 『한국도서관 - 정보학회지』, 40(1) : 317-338.

[6] 안영희, 이성숙. 2009. IFLA FRAD 모형이 관련 표준에 미친 영향 연구. 『정보관리학회지』, 26(1): 279-303.

[7] 中井万知子. 2008. “國立國會図書館の書誌データの今後：新方針を策定して”. 情報組織化 研究グループ7月月例研究會. [online]. [cited 2009.6.1].

〈http://www.tezuka-gu.ac.jp/public/seiken/meeting/2008/nakai20080719.pdf〉.

[8] Bibliographical Center for Research. 2009. Changes to MARC Formats Proposed. Weekly e-news alert. 2009.1.30. [online]. [cited 2009.6.1].

〈http://www.bcr.org/publications/bcreview/2009/01/changes-to-marc-formats-proposed.html〉.

[9] Block, Rick J. 2009. RDA: Boondoggle or Boon? And What About MARC? [online]. [cited 2009.6.8]. 〈http://www.nelib.org/netsl/conference/2009/RickBlock.pdf〉.

[10] Bushman, Barbara. 2009. Testing Resource Description and Access (RDA). Chicago: ALA Annual. July 11. [online]. [cited 2009.8.2].

〈http://presentations.ala.org/images/2/2f/TestingResourceDescriptionandAccess.ppt〉. 
[11] Calhoun, Karen. 2006. The Changing Nature of the Catalog and its Integration with Other Discovery Tools. [online]. [cited 2009.3.10]. 〈www.loc.gov/catdir/calhoun-report-final.pdf .

[12] Cataloging Futures blog. 2009. RDA: Resource Description and Access - more delays. [online]. [cited 2009.6.1]. 〈http://www.catalogingfutures.com/catalogingfutures/2008/08/rda-timeline---more-delays.h tml $>$.

[13] Chartered Institute of Library and Information Professionals. 2008. RDA: a cataloguing code for the 21st century. [online]. [cited 2008.12.1].

〈http://www.cilip.org.uk/publications/updatemagazine/archive/archive2008/september/rda chapman.htm>.

[14] Danskin, Alan. 2006. Tomorrow Never Knows: the End of Cataloguing? IFLA 2006 Seoul Session: ICABS. 2006. Aug. [online]. [cited 2009.3.10]. $\langle$ http://archive.ifla.org/IV/ifla72/papers/102-Danskin-en.pdf〉.

[15] Delsey, Tom. 2009. AACR2 versus RDA, CLA Pre-Conference Session: From Rules to Entities: Cataloguing with RDA, 2009. May 29. [online]. [cited.2009.6.1]. $\langle$ http://tsig.wikispaces.com/file/view/AACR2_versus_RDA.pdf $\rangle$.

[16] Hillmann, Diane. 2008. Facing Forward: The Challenges Facing Cataloging and Catalogers. [online]. [cited 2008. 12.1]. 〈http://hdl.handle.net/1813/11536〉.

[17] IFLA. 2009. Statement of International Cataloguing Principles. [online]. [cited 2009.3.10]. $\langle$ http://www.ifla.org/files/cataloguing/icp/ICP-2009_en.pdf〉.

[18] Espley, John. 2009. RDA and an ILS: Look Before You Leap Taking RDA for a Test-Drive. Chicago: ALA Annual. July 11. [online]. [cited.8.2]. 〈http://presentations.ala.org/images/4/46/LLL-Espley-VTLS-pt1_ALA2009.ppt〉.

[19] LC. 2008. Encoding RDA, Resource Description and Access data in MARC 21. MARC DISCUSSION PAPER NO. 2008-DP04. [online]. [cited 2008.12.12]. $\langle$ http://www.loc.gov/marc/marbi/2008/2008-dp04.html〉.

[20] LC. 2009a. Testing Resource Description and Access (RDA). [online]. [cited 2009.6.1]. $\langle$ http://www.loc.gov/bibliographic-future/rda/testing.html〉.

[21] LC. 2009b. Identifying work, expression, and manifestation records in the MARC 21 Bibliographic and Authority formats. MARC PROPOSAL NO. 2009-01/3. [online]. [cited 2008. 12.1]. 〈http://www.loc.gov/marc/marbi/2009/2009-01-3.html〉.

[22] LC. 2000. Bicentennial Conference on Bibliographic Control for the New Millennium: Con- 
fronting the Challenges of Networked Resources and the Web. [online]. [cited 2009.1.7]. $\langle$ http://www.loc.gov/catdir/bibcontrol/〉.

[23] Libraries Australia. 2009. Implementation scenarios, encoding structures and display. [online]. [cited 2009.6.23].

〈http://www.nla.gov.au/lis/stndrds/grps/acoc/documents/Walls2008.ppt〉.

[24] MARBI. 2009. MARC 21 Format 2009 Changes to Accommodate RDA (Draft). [online]. [cited 2009.6.23]. 〈http://www.loc.gov/marc/formatchanges-RDA.html〉.

[25] Marcum, Deanna B. 2005. The Future of Cataloging." Ebsco Leadership Seminar. [online]. [cited 2008.10.10]. 〈http://www.loc.gov/library/reports/CatalogingSpeech.pdf〉.

[26] Markey, Karen. 2007. The Online Library Catalog: Paradise Lost and Paradise Regained?" D-Lib Magazine, 13(1/2). [online]. [cited 2009.1.5].

$\langle$ http://www.dlib.org/dlib/january07/markey/01markey.html〉.

[27] OCLC. 2005. Perception of Libraries and Information Resources. [online]. [cited 2009.1.3]. $\langle$ http://www.oclc.org/reports/pdfs .

[28] The Joint Steering Committee for Development of RDA (JSC). 2007. RDA Implementation Scenarios. [online]. [cited 2009.8.1]. 〈http://www.rda-jsc.org/docs/5editor2.pdf〉.

[29] The Joint Steering Committee for Development of RDA (JSC). 2008. RDA, FRBR/FRAD, and Implementation Scenarios. [online]. [cited 2009.8]. $\langle$ http://www.rda-jsc.org/docs/5editor4.pdf $\rangle$.

[30] The Joint Steering Committee for Development of RDA (JSC). 2009. Adopting RDA. [online]. [cited 2009.2.1]. 〈http://www.rda-jsc.org/rdafaq.html\#9〉.

[31] University of california library. 2005. Rethinking how we provide bibliographic services for the University of California. [online]. [cited 2009.3.10].

〈http://libraries.universityofcalifornia.edu/sopag/BSTF/Final.pdf $\rangle$.

\section{- 국문 참고자료의 영어 표기}

(English translation / romanization of references originally written in Korean)

[1] Jin-Hee Park. 2009. "A Study on Movements to Establish RDA and Its Contents Structure." Journal of Korean Library and Information Science Society, 40(1): 317-338.

[2] Young-Hee Ahn, \& Sung-Sook Lee. 2009. "A Study on the Effects of the FRAD Model on the Related Standards." Journal of the Korean Society for Information Management, 26(1): 279-303. 